Article

\title{
Long-Term Productive, Competitive, and Economic Aspects of Spring Cereal Mixtures in Integrated and Organic Crop Rotations
}

\author{
Kazimierz Klima *(D), Agnieszka Synowiec*(D), Joanna Puła, Maciej Chowaniak (D, \\ Katarzyna Pużyńska ${ }^{D}$, Dorota Gala-Czekaj, Angelika Kliszcz, Patryk Galbas, Beata Jop, \\ Teresa Dąbkowska and Andrzej Lepiarczyk * \\ Department of Agroecology and Crop Production, Faculty of Agriculture and Economics, University of \\ Agriculture in Krakow, Al. Mickiewicza 21, 31-120 Krakow, Poland; joanna.pula@urk.edu.pl (J.P.); \\ maciek.chowaniak@gmail.com (M.C.); k.puzynska@urk.edu.pl (K.P.); d.gala@urk.edu.pl (D.G.-C.); \\ angelika.kliszcz@student.urk.edu.pl (A.K.); patryk.galbas@urk.edu.pl (P.G.); beata.jop@urk.edu.pl (B.J.); \\ t.dabkowska@urk.edu.pl (T.D.) \\ * Correspondence: rrklima@cyf-kr.edu.pl (K.K.); a.synowiec@urk.edu.pl (A.S.); \\ andrzej.lepiarczyk@urk.edu.pl (A.L.)
}

Received: 21 May 2020; Accepted: 12 June 2020; Published: 15 June 2020

\begin{abstract}
Cultivation of spring cereal mixtures (SCMs) is one of the ways to increase the yield of crops in mountainous areas of Poland. There are only a few current long-term studies on this topic. Our study aimed at analyzing yield and competitiveness as well as the economic indicators of spring cereals in pure or mixed sowings in integrated or organic crop rotations over nine years. A field experiment including pure sowings of oats, spring barley, or spring triticale and their two-component SCMs, each in two systems, organic and integrated crop rotation, was carried out in the Mountainous Experimental Station in Czyrna, Poland, in the years 2011-2019. On average, cereals in the pure sowings and mixtures yielded $18 \%$ lower in the organic rotations compared with the integrated ones. However, SCMs yielded higher than the pure sowings, and displayed a higher leaf area index and land equivalent ratio. The average gross margin without subsidies was almost two times higher in the organic crop rotations than in the integrated ones, which was influenced mainly by the cultivation of barley in pure sowing. Summing up, the cultivation of SCMs in the mountainous areas of southern Poland is advised because of both productive and economic factors.
\end{abstract}

Keywords: barley; oats; triticale; yield; leaf area index; land equivalent ratio; standard gross margin

\section{Introduction}

The cultivation of spring cereal mixtures (SCMs) is an element of crop rotation typical for Polish agriculture [1]. In 2015, cereals accounted for $73.3 \%$ of the total crop area of Poland, including $10.7 \%$ of SCMs. In 2017 and 2018, cereals accounted for 70.1\% and 72.1\%, respectively, and in the same years, the SCMs accounted for $11.6 \%$ and $12.7 \%$, respectively [2].

The spring cereal mixtures are applied both in organic and sustainable agricultural systems [3-5], mainly as a source of feed (grains) for livestock [6-8]. This method of crop cultivation involves the simultaneous sowing of usually two different species of spring cereals, in different proportions $[9,10]$; their grains are mixed before sowing.

Cultivation of SCMs has many advantages and is desirable in sustainable agriculture owing to current ecological trends related to reducing the amount of mineral fertilizers and pesticides, as a part of integrated pest management [11-13]. It results in less environmental pollution and lower outlays on agronomic practices [14]. This is because of the fact that SCMs are less infested by pathogens and insect 
pests than pure sowings $[15,16]$, which results from a reduced number of plants of a given species susceptible to a particular pest [17]. The components of mixtures are characterized by a different growth pattern [10], and as a result, they better cover soil, protecting it from water loss. This also results in a reduced weed infestation, as species in the mixture compete more effectively with weeds [18] and promote biodiversity in a canopy [19].

Many authors [20-22] confirmed the relationship between grain yield and leaf area index (LAI). LAI is referred to as the ratio of the surface of assimilation organs of a crop, mainly leaves, to the surface of soil. The LAI value depends on genetic characteristics and habitat factors [23]. For various crops, the LAI is several times larger than the surface of the soil, for example, for small-seeded legumes, 4-5 times, and for other crops, 2-4 times [24].

The SCMs are characterized by greater yield stability than pure sowing [25]. This is because of, among others, the fact that, in the adverse weather and soil conditions (e.g., drought) for the first species (component), the second component of the SCM finds more favorable conditions and increases the yield, compensating for the lower yield of the first one [26,27]. This compensation is also associated with the complementary use of soil resources, that is, nutrients and water, which results from the diverse architecture of the root systems of SCMs. Mixtures are an important element in increasing species diversity in crop rotation [28,29], which is supportive to stabilizing the yield of following crops [30].

A common component of SCMs is oats, called a phytosanitary plant [31]. Oats are a cereal species with a very well-developed root system, capable of taking water and nutrients from deeper layers of soil. Moreover, as an allelopathic crop, they influence, by root exudates, the abundance and composition of soil-pests, as well as the composition of soil microorganisms, which together contribute to the soil biological activity [32]. In this way, oats also stimulate the growth and development of the other component of SCM [33].

The available literature lacks current studies on the yield, competitiveness of components, and economic aspects of the cultivation of SCMs in different cropping systems, especially in the long term and in the extensive conditions of mountainous agriculture. Decisions related to the selection of the production structure are made based on both the production/quality characteristics and economic results [34], also including the system of agricultural subsidies [35]. Moreover, subsidies in the mountainous areas of southern Poland are one of the most important and motivating factors for a farmer to produce organically [3]. All of this became a reason for undertaking our research. The profitability of cultivation is determined by the relation between the value of the obtained crop and the incurred production costs, which include all elements throughout the production process. For this reason, our research also included economic analysis of standard gross margin of SCMs' cultivation.

The aims of our study were to (i) analyze the yield, competitiveness, and leaf area index (LAI); and (ii) assess the economic indicators of spring cereals in pure or mixed sowings in integrated or organic crop rotations, over nine years (three rotations of crops) in the mountainous area of southern Poland.

\section{Materials and Methods}

A field experiment was carried out in the years 2011-2019 in the Mountainous Experimental Station in Czyrna near Krynica Górska, southern Poland (545 m a.s.l.; 49 $25^{\prime}$, N 20 $58^{\prime}$ E). The soil was acid $\left(\mathrm{pH}_{\mathrm{KCl}}=5.1\right)$, brown soil—Cambisol [36], formed from weathered flysch material, composed of loam with a medium skeleton content. The chemical composition of soil was as follows: $0.22 \% \mathrm{~N}_{\text {tot. }}$; $46.2 \mathrm{mg} \mathrm{kg}^{-1}$ soil $\mathrm{P} ; 203.3 \mathrm{mg} \mathrm{kg}^{-1}$ soil $\mathrm{K} ; 1.84 \% \mathrm{C}_{\text {org}}$. The experiment was set up in a two-factorial split-block design, with four replications. The total area of a single plot was of $30.8 \mathrm{~m}^{2}$, with $22 \mathrm{~m}^{2}$ of a harvested area. Three full rotations of the crops (nine years) were included in the results.

There were two systems (first factor) of the experiment: (1) integrated, with mineral fertilization and chemical pesticides; and (2) organic, without any synthetic additives. Each of the systems was composed of six three-field crop rotations (second factor): (1) potato fertilized with manure (33 $\mathrm{t} \mathrm{ha}^{-1}$ ); (2) spring cereal pure sowing or a spring cereals mixture-six variants in total (Table 1); and (3) spring 
vetch. The density of cereals in the mixture was reduced by $50 \%$, in relation to the pure sowings. All of the systems and crops were present each year, which means that each crop was grown nine times throughout the whole study period. Three full rotations of the crops (nine years) were included in the results.

Table 1. Species composition and number of grains (pcs. $\mathrm{m}^{-2}$ ) for pure and mixed sowings of spring cereals.

\begin{tabular}{|c|c|}
\hline Species & Number of Germinating Grains \\
\hline \multicolumn{2}{|c|}{ Pure sowing ${ }^{1}$ : } \\
\hline Oats cv. Borowiak & 650 \\
\hline Spring barley cv. Boss & 410 \\
\hline Spring triticale cv. Wanad & 568 \\
\hline \multicolumn{2}{|c|}{ Mixture: } \\
\hline Oats + spring barley & $325+205$ \\
\hline Oats + spring triticale & $325+284$ \\
\hline Spring barley + spring triticale & $205+284$ \\
\hline
\end{tabular}

In the integrated crop rotation, a mineral fertilization for cereals in pure sowings and their mixtures was balanced, based on the content of nutrients in soil, quality of the preceding crop, and forecasted yield. In autumn, $34 \mathrm{~kg} \mathrm{ha}^{-1} \mathrm{P}$ and $55.6 \mathrm{~kg} \mathrm{ha}^{-1} \mathrm{~K}$ were applied before a deep ploughing in October. For cereals in spring, a total dose of $72.0 \mathrm{~kg} \mathrm{ha}^{-1} \mathrm{~N}$ was divided into two equal doses, one applied before sowing and a second in the shoot formation. Grains were coated with karboxine + thiram $(60 \mathrm{~g}+60 \mathrm{~g}$ per $100 \mathrm{~kg}$ of grains). Weeds in the pure sowings and mixtures were controlled by tribenuron methyl $\left(12 \mathrm{~g} \mathrm{ha}^{-1}\right)$.

In the organic crop rotation, no chemical fertilizers nor pesticides were applied. Weeds in the cereals were mechanically controlled by a Weeder harrow, run two times in by the end of tillering/beginning of shooting (BBCH 29-30 [37]).

In the stage of grains development (BBCH 70-71), samples of cereals were collected from each plot from $1 \mathrm{~m}^{2}$. An area of leaves was measured from 20 shoots per sample, using an LI-COR 3100 Area Meter (LI-COR Biosciences GmbH, Bad Homburg vor der Höhe, Germany). Next, the average area of leaves per shoot was multiplied by the total number of shoots per $1 \mathrm{~m}^{2}$ [24]. On this basis, a leaf area index (LAI) was calculated:

$$
\text { LAI }=\text { Leaf area }\left(\mathrm{m}^{2}\right) / \text { Ground cover }\left(\mathrm{m}^{2}\right),
$$

At harvest, the grain was collected from each plot $\left(22 \mathrm{~m}^{2}\right)$. The yield was expressed as per ha at $15 \%$ of seed moisture content.

To assess the competition between the components of the mixtures, two competition indices were calculated: land equivalent ratio (LER) (2) [38] and competitive ratio (CR) (3) [39].

$$
\begin{gathered}
\text { LER }=\text { LER } i+\text { LER } j, \\
\text { LER } i=Y i j / Y i i, \\
\text { LER } j=Y j i / Y j j,
\end{gathered}
$$

where Yii-yield of species $i$ in a pure sowing, Yjj-yield of species $j$ in a pure sowing, Yij-yield of species $i$ in a mixed sowing with a species $j$, and Yji-yield of species $j$ in a mixed sowing with a species $i$. 
If LER value is greater than one (LER > 1), it means that the mixture is more effective than the pure sowing [40,41].

$$
\begin{aligned}
& \mathrm{CR} i=(\mathrm{LER} i / \mathrm{LER} j)(\mathrm{Zji} / \mathrm{Zij}), \\
& \mathrm{CR} j=(\mathrm{LER} j / \text { LER } i)(\mathrm{Zij} / \mathrm{Zji}),
\end{aligned}
$$

where $Z i j$-proportion of species $i$ in the mixture with species $j$ and $Z j i-$ proportion of species $j$ in the mixture with species $i$.

If $\mathrm{CR}=1$, it means that there are equal competitive abilities of species $i$ and $j$. If $\mathrm{CR} i>1$, it means that species $i$ is more competitive than species $j$. If $C R i<1$, it means that species $j$ is more competitive than species $i[40-42]$.

The economic indicators were calculated. The amount of cash outlay on the means of production was taken as the basis for the agricultural techniques used in the experiment, as well as the consumption of pesticides, fertilizers, and seeds. The values were calculated per area of 1 hectare. The commodity value of the harvested crops and the prices of the means of production were according to data contained in the market analyses developed at the Department of Market Research IERiGZ-PIB, Warsaw, Poland [43]. An additional source of data was the farm production calculations compiled by the Department of Economics and Agricultural Management MODR, Karniowice, Poland [44]. All calculations took into account the prices of the last, that is, the year 2019. The average yield of crops during the 2011-2019 study period was included in the calculations. The amount of human labor expenditure was adopted [45]. The costs of agrotechnical operations were determined using the method [46]. The standard gross margin was calculated from the difference between the value of products obtained and the direct costs incurred. The direct profitability index, which characterizes the relation of production value to direct costs, was determined [47]. The labor consumption in the cultivation of cereals and cereal mixtures was 9.5 working hours per ha ${ }^{-1}$ and was based on the workload involved in the experiment.

The mean value of nine years was used in the statistical analysis. Before the examination, the results of the experiment were tested for normality of distribution as well as homogeneity of variance by Shapiro-Wilk and Brown-Forsythe tests (Statistica PL ver. 13.1, StatSoft, Krakow, Poland). Both tests turned insignificant values ( $p=0.1$ for both tests), a basis for performing the analysis of variance (ANOVA). The results were subjected to a two-factor ANOVA for a split-block design with four replications, using FR-ANALWAR-4.3 Microsoft Excel-based package (author: Prof. F. Rudnicki; UTP University of Science and Technology, Bydgoszcz, Poland). The significance of differences between means was tested using the Tukey test $(p \leq 0.05)$.

\section{Weather Conditions}

The weather data were collected from the meteorological station located in the Mountainous Experimental Station in Czyrna near Krynica Górska. The average precipitation in January, April, July, and August for the years 2011-2019 was similar for the multi-year (1962-1990) period. On average, the precipitation in May 2011-2019 was ca. $17 \mathrm{~mm}$ more, and in June 2011-2019 was ca. $24 \mathrm{~mm}$ less, than for the multi-year period (Table 2).

The average temperature for the vegetative period (April-August) of the 2011-2019 years was $2.4^{\circ} \mathrm{C}$ higher as compared with a similar period of a multi-year (Table 3). On average, April and August of the 2011-2019 years were particularly warmer than for a multi-year, by 2.8 and $3.4^{\circ} \mathrm{C}$, respectively. Moreover, the average temperatures in January and May-July of 2011-2019 were ca. $2{ }^{\circ} \mathrm{C}$ higher from those of the multi-year period (Table 3). 
Table 2. Sum of precipitation ( $\mathrm{mm}$ ) during the course of study.

\begin{tabular}{|c|c|c|c|c|c|c|c|c|c|c|c|c|c|c|}
\hline \multirow{2}{*}{ Year } & \multicolumn{12}{|c|}{ Month } & \multirow{2}{*}{$\begin{array}{l}\text { Ap.- } \\
\text { Ag. }\end{array}$} & \multirow{2}{*}{$\begin{array}{l}\text { J.- } \\
\text { Dc. }\end{array}$} \\
\hline & $\mathrm{J}$. & Fb. & Mr. & Ap. & M. & Jn. & Jl. & Ag. & Sp. & Oc. & Nv. & Dc. & & \\
\hline 2011 & 36.7 & 15.1 & 27.6 & 106.3 & 72.1 & 44.4 & 278.4 & 85.6 & 15.9 & 34 & 11.1 & 15 & 586.8 & 742.2 \\
\hline 2012 & 60.9 & 33.2 & 20.5 & 56.6 & 20.6 & 167.7 & 82.2 & 63.3 & 45.4 & 108 & 25.8 & 31.6 & 390.4 & 715.8 \\
\hline 2013 & 74.1 & 26.6 & 38.4 & 24.7 & 118 & 202.4 & 33.1 & 32.9 & 109.6 & 18 & 92.9 & 29.7 & 411.1 & 800.4 \\
\hline 2014 & 45.8 & 21.2 & 39.2 & 51.1 & 137.8 & 58.3 & 134.4 & 113.6 & 72.7 & 39.6 & 45.2 & 47.5 & 495.2 & 806.4 \\
\hline 2015 & 58.8 & 32.2 & 45.4 & 50.5 & 123.8 & 43.5 & 52.1 & 83.7 & 82.5 & 51.3 & 43.8 & 52.1 & 353.6 & 719.7 \\
\hline 2016 & 21.6 & 73.8 & 36.6 & 62.4 & 56.2 & 62 & 173.1 & 116.9 & 55.9 & 140.5 & 49.7 & 53.6 & 470.6 & 902.3 \\
\hline 2017 & 162.5 & 81.2 & 45.4 & 121.6 & 69.1 & 38.5 & 100.3 & 89.7 & 189.8 & 59.4 & 53.6 & 42.1 & 419.2 & 1053.2 \\
\hline 2018 & 67.4 & 11.8 & 16.5 & 25.1 & 82.4 & 85.2 & 118.6 & 85.4 & 85.1 & 53.7 & 48.5 & 42.3 & 396.7 & 722 \\
\hline 2019 & 51.4 & 15.8 & 25.4 & 85.3 & 234.2 & 26.7 & 60.6 & 94 & 89.7 & 42.5 & 39.1 & 51.6 & 500.8 & 816.3 \\
\hline 2011-2019 & 64.4 & 34.5 & 32.8 & 64.8 & 101.6 & 81 & 114.8 & 85 & 83 & 60.8 & 45.5 & 40.6 & 447.2 & 808.7 \\
\hline $1961-1990^{1}$ & 58.1 & 46.9 & 48 & 62.2 & 84.9 & 105 & 114.9 & 98.3 & 78.7 & 56 & 43.9 & 51.2 & 465.3 & 848.1 \\
\hline
\end{tabular}

Table 3. Mean temperatures $\left({ }^{\circ} \mathrm{C}\right)$ during the course of study.

\begin{tabular}{|c|c|c|c|c|c|c|c|c|c|c|c|c|c|c|}
\hline \multirow{2}{*}{ Year } & \multicolumn{12}{|c|}{ Month } & \multirow{2}{*}{$\begin{array}{l}\text { Ap.- } \\
\text { Ag. }\end{array}$} & \multirow{2}{*}{$\begin{array}{l}\text { J.- } \\
\text { Dc. }\end{array}$} \\
\hline & $\mathrm{J}$. & Fb. & Mr. & Ap. & M. & Jn. & Jl. & Ag. & Sp. & Oc. & Nv. & Dc. & & \\
\hline 2011 & -2.5 & -4 & 2.2 & 8.9 & 12.3 & 17.1 & 16.3 & 17.9 & 12.6 & 7.2 & 1.6 & -0.1 & 14.5 & 7.47 \\
\hline 2012 & -2.6 & -7.9 & 3.1 & 8.2 & 13.8 & 16.2 & 18.9 & 17.7 & 12.7 & 7.3 & 3.7 & -3.8 & 14.9 & 7.27 \\
\hline 2013 & -3.7 & -1.6 & -2.1 & 7.2 & 13.1 & 15.5 & 18.1 & 17.7 & 11.4 & 8.7 & 3.6 & -0.1 & 14.3 & 7.3 \\
\hline 2014 & -3 & 0.7 & 5.3 & 8.5 & 12.6 & 14.4 & 18.7 & 16.2 & 13.9 & 8.8 & 3.7 & -0.9 & 14 & 8.32 \\
\hline 2015 & -0.1 & 1 & 3.1 & 7 & 11.6 & 15.7 & 18.9 & 20.2 & 13.2 & 7.8 & 1.1 & -2.4 & 14.6 & 7.92 \\
\hline 2016 & -3.6 & 2.5 & 3.5 & 7.8 & 12.8 & 17.5 & 18.1 & 16.6 & 14.2 & 6.8 & 1 & -2.5 & 14.5 & 7.9 \\
\hline 2017 & -6.8 & -1.1 & 4.9 & 6.2 & 12.3 & 16.8 & 17.7 & 18.4 & 11.6 & 7.3 & 1.4 & -2.4 & 14.2 & 7.19 \\
\hline 2018 & -0.3 & -4.4 & -0.7 & 12.5 & 15.8 & 17.1 & 18.6 & 19.3 & 12.1 & 7.1 & 1.5 & -2.2 & 16.6 & 8.01 \\
\hline 2019 & -1.6 & -3.8 & 0.8 & 14.9 & 16 & 18.1 & 19.3 & 20.2 & 12.1 & 8.1 & 1.2 & -1.8 & 17.7 & 8.62 \\
\hline $2011-2019$ & -2.7 & -2.1 & 2.2 & 9 & 13.4 & 16.5 & 18.3 & 18.2 & 12.6 & 7.7 & 2.1 & -1.8 & 15 & 7.8 \\
\hline $1961-1990^{1}$ & -4.4 & -3.2 & 1.2 & 6.2 & 11.5 & 14.2 & 16 & 14.8 & 11.2 & 7 & 0.9 & -2.7 & 12.6 & 6.1 \\
\hline
\end{tabular}

\section{Results}

\subsection{Yield of Cereals in Pure Sowings and Mixtures}

The average yield of grain of spring cereals in the organic crop rotation was $18 \%$ lower than in the integrated one (Table 4). On average, spring cereal mixtures (SCMs) yielded 8.5\% higher than pure sowings. For pure sowings, the lowest was the yield of oats, by $13 \%$ less than that of spring barley. Among SCMs, the highest yield was for oats and barley, by $22.6 \%$ more than for oats in pure sowing. Moreover, the average yield of a mixture of oats and triticale was $8.4 \%$ higher than the yield of oats in pure sowing. The yield of a mixture of triticale and barley was similar to that of a barley in pure sowing, but $11.4 \%$ higher than triticale in pure sowing (Table 4 ). 
Table 4. Grain yield $\left(\mathrm{t} \mathrm{ha}^{-1}\right)$ of spring cereals grown in pure sowings or in mixtures in integrated or organic crop rotation, means for the years 2011-2019.

\begin{tabular}{cccc}
\hline \multirow{2}{*}{ Cereal/Cereal Mixture } & \multicolumn{2}{c}{ Crop Rotation } & \multirow{2}{*}{ Mean ${ }^{\mathbf{1}}$} \\
\cline { 2 - 3 } & Integrated & Organic & \\
\hline Oats & 4.14 & 3.21 & $3.67 \mathrm{~A}$ \\
Spring barley & 4.58 & 3.73 & $4.15 \mathrm{C}$ \\
Spring triticale & 4.18 & 3.35 & $3.76 \mathrm{AB}$ \\
Oats + spring barley & 4.86 & 4.15 & $4.50 \mathrm{D}$ \\
Oats + spring triticale & 4.37 & 3.6 & $3.98 \mathrm{BC}$ \\
Spring triticale + spring & 4.55 & 3.84 & $4.19 \mathrm{C}$ \\
barley & $4.44 \mathrm{~B}$ & $3.64 \mathrm{~A}$ & \\
Mean & & & \\
\hline
\end{tabular}

${ }^{1}$ Means with various letters are significantly different, according to Tukey test $(p \leq 0.05)$.

The grain yield of individual components of SCMs was significantly differentiated (Table 5). On average, grain yields in the integrated crop rotations were 19\% higher than in the organic ones. The lowest yield was for the oats in the mixture with triticale in the organic crop rotation. In turn, the barley mixed with oats in the integrated crop rotation yielded the highest (Table 5).

Table 5. Grain yields $\left(\mathrm{t} \mathrm{ha}^{-1}\right)$ of the components of the spring cereal mixtures in the integrated or organic crop rotations, means for the years 2011-2019.

\begin{tabular}{|c|c|c|c|}
\hline \multirow{2}{*}{ Component of Mixture } & \multicolumn{2}{|c|}{ Crop Rotation } & \multirow{2}{*}{ Mean } \\
\hline & Integrated & Organic & \\
\hline Oats + & $2.24 \mathrm{ef}$ & $1.86 \mathrm{~b}$ & $2.05 \mathrm{~A}$ \\
\hline spring barley & $2.62 \mathrm{~h}$ & $2.29 \mathrm{f}$ & $2.45 \mathrm{C}$ \\
\hline Oats + & $2.15 \mathrm{~d}$ & $1.74 \mathrm{a}$ & $1.94 \mathrm{~A}$ \\
\hline spring triticale & $2.22 \mathrm{e}$ & $1.86 \mathrm{~b}$ & $2.04 \mathrm{~A}$ \\
\hline Spring barley + & $2.35 \mathrm{~g}$ & $1.97 \mathrm{c}$ & $2.16 \mathrm{~B}$ \\
\hline spring triticale & $2.2 \mathrm{de}$ & $1.87 \mathrm{~b}$ & $2.03 \mathrm{~A}$ \\
\hline Mean ${ }^{1}$ & $2.29 \mathrm{~B}$ & $1.93 \mathrm{~A}$ & \\
\hline
\end{tabular}

${ }^{1}$ Means/values with various letters are significantly different, according to Tukey test $(p \leq 0.05)$.

\subsection{Leaf Area Index of Cereals in Pure Sowings and Mixtures}

The data presented in Table 6 show that the distribution of average values of leaf area index (LAI) for both crop rotations, as well as pure sowings and SCMs, was similar to those for the grain yield (Table 3). The mean value of LAI for the integrated crop rotations was significantly higher than for the organic ones. The values of LAI for SCMs were 9.7\% higher than for pure sowings. The highest LAI was recorded for a mixture of oats and barley; it was higher than that of a pure sowing of oats and pure sowing of barley, by $28 \%$ and $8 \%$, respectively. 
Table 6. Leaf area index $\left(\mathrm{m}^{2} \mathrm{~m}^{-2}\right)$ of cereals in pure sowings or in mixtures in integrated or organic crop rotations, means for the years 2011-2019.

\begin{tabular}{cccc}
\hline \multirow{2}{*}{ Cereal/Cereal Mixture } & \multicolumn{2}{c}{ Crop Rotation } & \multirow{2}{*}{ Mean ${ }^{\mathbf{1}}$} \\
\cline { 2 - 3 } & Integrated & Organic & \\
\hline Oats & 1.93 & 1.5 & $1.71 \mathrm{~A}$ \\
Spring barley & 2.23 & 1.82 & $2.02 \mathrm{BC}$ \\
Spring triticale & 2.07 & 1.67 & $1.87 \mathrm{AB}$ \\
Oats + spring barley & 2.36 & 2.02 & $2.19 \mathrm{D}$ \\
Oats + spring triticale & 2.12 & 1.76 & $1.94 \mathrm{~B}$ \\
Spring triticale + spring & 2.25 & 1.9 & $2.07 \mathrm{CD}$ \\
barley & $2.16 \mathrm{~B}$ & $1.77 \mathrm{~A}$ & \\
Mean & & & \\
\hline
\end{tabular}

${ }^{1}$ Means with various letters are significantly different, according to Tukey test $(p \leq 0.05)$.

A detailed analysis of LAI for the components of the mixtures revealed that oats in the SCMs had a significantly lower LAI; each time, the value of LAI of oats in the SCMs was below 1 . The highest LAI was recorded for barley in the SCMs. What is more, the LAI of barley in the mixture with oats was $30 \%$ higher than that of oats (Table 7 ).

Table 7. Leaf area index $\left(\mathrm{m}^{2} \mathrm{~m}^{-2}\right)$ of the components of the spring cereal mixtures in integrated or organic crop rotations, means for the years 2011-2019.

\begin{tabular}{cccc}
\hline \multirow{2}{*}{ Component of Mixture } & \multicolumn{2}{c}{ Crop Rotation } & Mean ${ }^{\mathbf{1}}$ \\
\cline { 2 - 4 } & Integrated & Organic & \\
\hline Oats + & 1.04 & 0.86 & $0.95 \mathrm{~B}$ \\
spring barley & 1.32 & 1.16 & $1.24 \mathrm{E}$ \\
Oats + & 1.01 & 0.81 & $0.91 \mathrm{~A}$ \\
spring triticale & 1.11 & 0.95 & $1.03 \mathrm{C}$ \\
Spring barley + & 1.15 & 0.96 & $1.05 \mathrm{D}$ \\
spring triticale & 1.1 & 0.94 & $1.02 \mathrm{C}$ \\
Mean ${ }^{1}$ & $1.12 \mathrm{~B}$ & $0.94 \mathrm{~A}$ & \\
\hline
\end{tabular}

${ }^{1}$ Means with various letters are significantly different, according to Tukey test $(p \leq 0.05)$.

\subsection{Competition Indices for the Mixtures}

Expressing the cereal grain yields as a land equivalent ratio (LER), which shows the productivity of the SCMs, it was found that the LER values for all the SCMs were higher than 1 (Table 8). An SCM of oats with barley, followed by a mixture of oats with triticale and a mixture of barley with triticale, had the highest yielding potential, that is, the highest LER. Moreover, the system of crop rotation, integrated or organic, significantly differentiated the LER value, which was on average $4 \%$ higher in the organic system.

Table 8. Values of land equivalent ratio (LER) for the components of the spring cereal mixtures in integrated or organic crop rotations, means for the years 2011-2019.

\begin{tabular}{|c|c|c|c|c|c|c|}
\hline \multirow{3}{*}{ Component of Mixture } & \multicolumn{6}{|c|}{ Crop Rotation } \\
\hline & \multicolumn{2}{|l|}{ Integrated } & \multicolumn{2}{|l|}{ Organic } & \multicolumn{2}{|l|}{ Mean } \\
\hline & Component of Mixture & Sum ${ }^{1}$ & Component of Mixture & Sum 1 & Component of Mixture & Sum $^{1}$ \\
\hline $\begin{array}{c}\text { Oats }+ \\
\text { spring barlev }\end{array}$ & 0.54 & $1.11 \mathrm{~B}$ & 0.57 & $1.18 \mathrm{~B}$ & 0.55 & $1.14 \mathrm{~B}$ \\
\hline Oats + & 0.52 & & 0.54 & & 0.53 & \\
\hline spring triticale & 0.53 & $1.05 \mathrm{~A}$ & 0.55 & $1.09 \mathrm{~A}$ & 0.54 & $1.07 \mathrm{~A}$ \\
\hline Spring barley + & 0.51 & $1.03 \mathrm{~A}$ & 0.53 & $1.08 \mathrm{~A}$ & 0.52 & $1.05 \mathrm{~A}$ \\
\hline spring triticale & 0.52 & & 0.55 & $111 \mathrm{~b}$ & & \\
\hline Mean ${ }^{1}$ & & $1.06 \mathrm{a}$ & & $1.11 \mathrm{~b}$ & & \\
\hline
\end{tabular}

${ }^{1}$ Means/sums with various letters are significantly different, according to Tukey test $(p \leq 0.05)$. 
On contrary, the competitive ratio (CR) for the integrated and organic crop rotations was similar (Table 9). For this indicator, both the competitor's species and the component species in the SCM were key. Thus, triticale had the highest CR in the SCMs. Barley was a competitor to oats but underwent competitive pressure when mixed with triticale. Oats undergo competitive pressure in all of the SCMs, with spring barley being the strongest competitor to it.

Table 9. Values of competitive ratio (CR) of the components of the spring cereal mixtures, means for the years 2011-2019.

\begin{tabular}{cccc}
\hline \multirow{2}{*}{ Component of Mixture } & \multicolumn{2}{c}{ Crop Rotation } & \multirow{2}{*}{ Mean ${ }^{\mathbf{1}}$} \\
& Integrated & Organic & $0.93 \mathrm{~A}$ \\
Oats + & 0.94 & 0.93 & $1.06 \mathrm{C}$ \\
spring barley & 1.05 & 1.07 & $0.98 \mathrm{~B}$ \\
Oats + & 0.98 & 0.98 & $1.02 \mathrm{BC}$ \\
spring triticale & 1.02 & 1.02 & $0.97 \mathrm{AB}$ \\
Spring barley + & 0.98 & 0.96 & $1.03 \mathrm{C}$ \\
spring triticale & 1.02 & 1.04 & \\
Mean ${ }^{1}$ & 0.99 & 1 & \\
\hline
\end{tabular}

${ }^{1}$ Means with various letters are significantly different, according to Tukey test $(p \leq 0.05)$.

\subsection{Economic Indices for the Mixtures}

The results presented in Table 10 relate to research carried out in the mountainous area of southern Poland. The basic function of these areas is protection and retention of water resources. Table 10 contains economic measures for the cultivation of spring cereals and spring cereals mixtures. The average direct costs in the integrated system (EUR $481.9 \mathrm{ha}^{-1}$ ) were $39.1 \%$ higher than in the organic system (EUR $293.5 \mathrm{ha}^{-1}$ ). The highest share in the direct costs in the integrated system can be attributed to the application of mineral fertilizers, EUR $138.5 \mathrm{ha}^{-1}$ on average.

Table 10. Economic indicators of pure and mixed sowings of spring cereals in integrated or organic crop rotations (EUR ha ${ }^{-1}$ ); prices for the year 2019.

\begin{tabular}{|c|c|c|c|c|c|c|c|c|c|c|c|c|c|c|}
\hline \multirow{3}{*}{ Source of Cost } & \multicolumn{6}{|c|}{ Pure Sowing } & \multicolumn{6}{|c|}{ Spring Cereal Mixture } & \multicolumn{2}{|c|}{ Mean } \\
\hline & \multicolumn{2}{|c|}{ Oats } & \multicolumn{2}{|c|}{ Barley } & \multicolumn{2}{|c|}{ Triticale } & \multicolumn{2}{|c|}{ Oats + Barley } & \multicolumn{2}{|c|}{ Oats + Triticale } & \multicolumn{2}{|c|}{ Triticale + Barley } & \multirow{2}{*}{ I } & \multirow{2}{*}{$\mathbf{O}$} \\
\hline & $\mathbf{I}$ & $\mathbf{O}$ & $\mathbf{I}$ & $\mathbf{O}$ & I & $\mathbf{O}$ & I & $\mathbf{O}$ & $\mathbf{I}$ & $\mathbf{O}$ & $\mathbf{I}$ & $\mathbf{O}$ & & \\
\hline Input costs & 544.3 & 421.9 & 612.8 & 499.2 & 588.9 & 471.9 & 570.6 & 496.8 & 523.1 & 431.1 & 544.7 & 459.7 & 564.0 & 463.3 \\
\hline $\begin{array}{l}\text { SGM without } \\
\text { subsidies }\end{array}$ & 57.7 & 123.7 & 138.6 & 214.4 & 103.7 & 175.1 & 89.9 & 204.7 & 37.2 & 133.6 & 64.9 & 168.3 & 82.1 & 169.8 \\
\hline SGM with subsidies & 235.6 & 487.6 & 316.5 & 578.3 & 281.6 & 539.0 & 267.8 & 568.6 & 215.1 & 497.5 & 242.8 & 532.2 & 260.0 & 533.7 \\
\hline $\begin{array}{l}\text { Share of subsidies in } \\
\text { the SGM }(\%)\end{array}$ & 75 & 74 & 56 & 63 & 63 & 67 & 66 & 64 & 82 & 73 & 73 & 68 & 68 & 68 \\
\hline \multicolumn{15}{|c|}{ Direct profitability index } \\
\hline Without subsidies & 1.11 & 1.41 & 1.29 & 1.74 & 1.21 & 1.58 & 1.18 & 1.69 & 1.07 & 1.44 & 1.13 & 1.57 & 1.17 & 1.57 \\
\hline With subsidies & 1.48 & 2.63 & 1.66 & 3.01 & 1.57 & 2.81 & 1.55 & 2.94 & 1.44 & 2.67 & 1.50 & 2.82 & 1.53 & 2.81 \\
\hline
\end{tabular}

I-integrated; O-organic; SGM-standard gross margin. Conversion rate of 1 EUR $=4.2585$ PLN in accordance with the National Polish Bank exchange rate on 31 December 2019.

The average value of direct surplus without subsidies was almost twofold higher in the organic system than in the integrated one. A greater disproportion between the examined systems occurred, when subsidies were added to the direct surplus (Table 10). The sum of subsidies for both cereals in pure sowing and mixtures is the same, and equal to EUR $177.9 \mathrm{ha}^{-1}$ and EUR $363.9 \mathrm{ha}^{-1}$ in the integrated and organic system, respectively.

The highest value of direct surplus without subsidies, among spring cereals, was obtained for spring barley (Table 10). This was because of the fact that pure sowings of spring barley yielded highest. The SCM of oats with barley also yielded high; however, the purchase price of the SCM grains was on average $10 \%$ lower than that of spring barley grains. 


\section{Discussion}

Our study presents the results of a nine-year-long field experiment with six different crop rotations, each in two systems-integrated and organic. The results indicated that the average yield of spring cereal grain obtained during the next nine growing seasons in the organic crop rotation was about $18 \%$ lower than in the integrated one. This mainly results from the lack of use of easily absorbable fertilizers, as well as pesticides in the organic system. As shown by Kumar et al. [48], at low nutrient availability, especially during early growth of cereals, higher investments in root system development can significantly trade off with aboveground productivity, and strong competition can further strengthen such effects.

It was also found that, in both systems, the yielding of two-species spring cereal mixtures (SCMs) was higher than the cereals in pure sowing, which is consistent with the results of other authors [26,27]. This phenomenon consists of a number of factors, including the complementary use of habitat resources [49] or mutually stimulating allelopathic effect of cereals [50].

Of the three different SCMs, oats with spring barley, oats with spring triticale, and spring triticale with spring barley, higher yields were observed for the mixtures with barley as a component. A mixture of oats and barley was characterized by a particularly high grain yield. Barley was the dominant component in this mixture, which posed a strong competitive effect on oats, as indicated by its high competitiveness ratio $(C R=1.06)$. Moreover, the barley yield in the mixture with oats was high, and even higher than in pure sowing, taking into account that the plant density reduced by half in mixture compared with pure sowing. Despite the dominance of barley in the mixture with oats, both components of this mixture act complementarily. Spring barley is a low cereal, but with a fast growth rate, high tillering, and a short ripening period [51]. On the contrary, oats are a high cereal, ripening relatively late. As pointed by Shaaf et al. [52], faster initial growth of spring barley favors its stronger tillering. This results in a competitive advantage of spring barley over oats in the early stages of growth [53,54]. Sobkowicz [55] points out that, in the phase of emergence, a competition of root systems for soil resources is more important than those of the aboveground parts for light. This applies especially to spring barley, which, in the early phases of growth, produces a large root system [55]. According to Cousens [56], competition for light begins in the tillering phase. The competitive advantage of oats over spring barley begins in the flowering phase. From this phase, plants of oats are higher than spring barley plants. As pointed by Hecht et al. [57], in later growth phases, when barley density is higher, the stem mass fraction increases, while the root mass fraction decreases. In the later growth period (watery ripe, $\mathrm{BBCH} 71$ ), higher plants of oats develop greater panicles and grains [53]. So-called height convergence may be observed for the mixtures; specifically, a shortening of the long-culmed cereal species and an increase in the length of the short-culmed species. As a result, the mixtures have a decreased lodging and a higher yield [58]. This phenomenon can also be observed for the mixture of oats and barley [59].

In the present study, a high value of the land equivalent ratio (LER), which is an indicator of crop productivity [60], was also found for the SCMs. This is consistent with the results of other authors [61]. Interestingly, the average sum of LERs for the SCMs in the organic system was equal to 1.11 and was significantly higher than for those SCMs in the integrated system. This may indicate a complementary and more effective use by the components of SCMs of limited habitat resources, especially in the organic system. Rudnicki [62] showed that, as soil conditions deteriorate, the SCMs are more effective compared with pure sowing. However, at better and fertilized crop stands, the yields of mixtures are similar to the yields of pure sowing. Among the examined SCMs, the highest LER value was recorded for a mixture of oats with spring barley (LER $=1.14$ ). This result further confirms the complementarity of the components of this mixture.

In the scientific literature so far, there are no detailed results of studies on the leaf area index (LAI) of SCMs. Available studies on LAI of pure cereal sowing show that there is a directly proportional relationship between this trait and grain yield [63]. Our results may partly explain the tendency to obtain higher yields of SCMs in comparison with pure sowing. The results of this study showed that, 
in both SCMs containing barley, the LAI value was the highest, and the presence of barley affected this result. This likely resulted from the difference in the height of the components of the mixtures. Barley, as a low cereal, develops leaves in the lower layers of the canopy, and effectively uses space for assimilation of photosynthetically active radiation.

Organic farming is perceived as an agricultural system that balances multiple sustainability goals by promoting global food and ecosystem security. Whether organic agriculture can expand is determined by its economic competitiveness with the other agricultural systems [64,65]. In our study, we found that the average value of standard gross margin without subsidies was almost twofold higher in the organic crop rotation than in the integrated one. This result is perspective for an organic system and is in accordance with research by Crowder and Reganold [64]. They examined the financial performance of organic and conventional agriculture by conducting a meta-analysis of a global dataset spanning 55 crops grown on five continents. They found out that, without organic premiums, benefit/cost ratios and net present values of organic agriculture were significantly lower than those for conventional agriculture. However, when actual premiums were applied, organic agriculture was significantly more profitable (22-35\%) and had higher benefit/cost ratios (20-24\%) than conventional agriculture. The authors conclude that organic agriculture can continue to expand even if premiums decline [64]. On the contrary, Rosa-Schleich et al. [66] underline that the ecological benefits for the farmer were partly insufficient to outbalance economic costs in the short term, even though these practices have the potential to lead to higher and more stable yields, increase profitability, and reduce risks in the long term. Still, ecological-economic performance of organic practices is highly context-dependent [66]. One of the factors that can increase profits and reduce the risks of the organic cropping system is a proper selection of crops $[67,68]$. In our research, this condition was met by including pure sowing of spring barley in the crop rotation. As shown by Omokanye et al. [8], the profits from cultivating mixtures are variable, and not always higher than those of selected crops in pure sowings. Moreover, a significant role in our research was played by subsidies, which are of the highest importance in both the organic system as well as the mountainous areas of southern Poland, where the less favored conditions occur [35].

\section{Conclusions}

The results of our long-term research carried out in the mountainous areas of southern Poland revealed that yield of SCMs and leaf area index in pure and mixed sowing in the organic crop rotation was lower than in the integrated one, by $18 \%$ and $16 \%$, respectively. At the same time, the average yield of spring cereal mixtures with barley was higher than that of pure cereal sowing. Under the conditions studied, the highest yield was obtained for a mixture of oats and spring barley, which could be partially explained by the higher leaf area index value for this mixture (LAI $=2.19$ ). The yields of the other mixtures (oats with spring triticale and spring triticale with spring barley) were higher than the yield of the one of the components of the mixture in pure sowing. Moreover, the average sum of LERs for mixtures in the organic system was 1.11 and was significantly higher than for mixtures in the integrated system. In mixtures, barley displayed the highest competitiveness ratio. The analysis of the land equivalent ratio (LER) also showed that, under the examined conditions, spring cereal mixtures are a more effective form of cultivation than pure sowings. Each time, LER values for the mixtures exceeded 1. At the same time, despite lower yields of spring cereals in the organic crop rotation, the average value of standard gross margin without subsidies in the organic crop rotation was almost twice as high as in the integrated one. Among pure and mixed sowings, the highest value of standard gross margin without subsidies was found for spring barley cultivation. Summing up, ecological cultivation of spring cereal mixtures, having many pro-environmental values and showing a standard gross margin, should be recommended especially in the mountainous areas of southern Poland.

Author Contributions: Conceptualization, K.K.; methodology, K.K.; validation, A.L.; formal analysis, K.K. and A.S.; investigation, K.K., M.C., and P.G.; resources, A.L.; data curation, K.K., P.G., and A.K.; writing-original draft preparation, A.S., J.P., K.P., and B.J.; writing—review and editing, T.D., A.K., and D.G.-C.; visualization, K.K., 
A.S., and T.D.; supervision, K.K.; project administration, K.K. and A.L.; funding acquisition, K.K. All authors have read and agreed to the published version of the manuscript.

Funding: This research was funded by the Ministry of Science and Higher Education of Republic of Poland, grant number DS 3124.

Conflicts of Interest: The authors declare no conflict of interest.

\section{References}

1. Leszczyńska, D. State and conditions of cultivation of grain crops mixtures in Poland. J. Res. Appl. Agric. Eng. 2007, 52, 105-108.

2. Statistics Poland. Concise Statistical Yearbook of Poland; Zakład Wydawnictw Statystycznych: Warsaw, Poland, 2018. Available online: https:/stat.gov.pl/files/gfx/portalinformacyjny/pl/defaultaktualnosci/5515/1/19/1/ maly_rocznik_statystyczny_polski_2018.pdf (accessed on 20 May 2020).

3. Klima, K.; Łabza, T. Yielding and economic efficiency of oats crop cultivated using pure and mixed sowing stands in organic and conventional farming systems. Zywn.-Nauk. Technol. Ja. 2010,17, 141-147.

4. Kaut, A.H.E.E.; Mason, H.E.; Navabi, A.; O’Donovan, J.T.; Spaner, D. Organic and conventional management of mixtures of wheat and spring cereals. Agron. Sust. Develop. 2008, 28, 363-371. [CrossRef]

5. Sobkowicz, P.; Tendziagolska, E.; Łagocka, A. Response of oat-triticale mixture to post-emergence weed harrowing. Acta Agric. Scand. B. 2020, 70, 307-317. [CrossRef]

6. Jedel, P.E.; Salmon, D.F. Forage potential of spring and winter cereal mixtures in a short-season growing area. Agron. J. 1995, 87, 731-736. [CrossRef]

7. Juskiw, P.E.; Helm, J.H.; Salmon, D.F. Forage yield and quality for monocrops and mixtures of small grain cereals. Crop. Sci. 2000, 40, 138-147. [CrossRef]

8. Omokanye, A.; Lardner, H.; Lekshmi, S.; Jeffrey, L. Forage production, economic performance indicators and beef cattle nutritional suitability of multispecies annual crop mixtures in northwestern Alberta, Canada. J. Appl. Anim. Res. 2019, 47, 303-313. [CrossRef]

9. Juskiw, P.E.; Helm, J.H.; Salmon, D.F. Competitive ability in mixtures of small grain cereals. Crop. Sci. 2000, 40, 159-164. [CrossRef]

10. Juskiw, P.E.; Helm, J.H.; Salmon, D.F. Postheading biomass distribution for monocrops and mixtures of small grain cereals. Crop Sci. 2000, 40, 148-158. [CrossRef]

11. Smithson, J.B.; Lenne', J.M. Varietal mixtures: A viable strategy for sustainable productivity in subsistence agriculture. Ann. Appl. Biol. 1996, 128, 127-158. [CrossRef]

12. Wolfe, M.S.; Baresel, J.P.; Desclaux, D.; Goldringer, I.; Hoad, S.; Kovacs, G.; Loeschenberger, F.; Miedaner, T.; Østergard, H.; Lammerts van Bueren, E.T. Developments in breeding cereals for organic agriculture. Euphytica 2008, 163, 323-346. [CrossRef]

13. Pappa, V.A.; Rees, R.M.; Walker, R.L.; Baddeley, J.A.; Watson, C.A. Legumes intercropped with spring barley contribute to increased biomass production and carry-over effects. J. Agric. Sci. 2011, 150, 584-594. [CrossRef]

14. Klima, K.; Stokłosa, A.; Pużyńska, K. Agricultural and economic circumstances of cereal cultivation under differentiated soil and climate conditions. Zesz. Probl. Postęp. Nauk Rol. 2011, 559, 115-121.

15. Finckh, M.R.; Gacek, E.S.; Goyeau, H.; Lannou, C.; Ueli, M.; Mundt, C.C.; Munk, L.; Nadziak, J.; Newton, A.C.; de Vallavieille-Pope, $\mathrm{C}$; et al. Cereal variety and species mixtures in practice, with emphasis on disease resistance. Agronomie 2000, 20, 813-837. [CrossRef]

16. Dambolena, J.S.; Lopez, A.G.; Meriles, J.M.; Rubinstein, H.R.; Zygadlo, J.A. Inhibitory effects of 10 natural phenolic compounds on Fusarium verticillioides. A structure-property activity relationship study. Food Cont. 2012, 28, 163-170. [CrossRef]

17. Finckh, M.R.; Wolfe, M.S. The use of biodiversity to restrict plant diseases and some consequences for farmers and society. In Ecology in Agriculture, 1st ed.; Jackson, L.E., Ed.; Academic Press: San Diego, CA, USA, 1997; pp. 199-233.

18. Hiltbrunner, J.; Jeanneret, P.; Liedgens, M.; Stamp, P.; Streit, B. Response of weed communities to legume living mulches in winter wheat. J. Agron. Crop. Sci. 2007, 193, 93-102. [CrossRef]

19. Rajaniemi, T.K.; Allison, V.J.; Goldberg, D.E. Root competition can cause a decline in diversity with increased productivity. J. Ecol. 2003, 91, 407-416. [CrossRef] 
20. Woźniak, A.; Gontarz, D.; Staniszewski, M. Effect of crop rotation on yielding and leaf area index (LAI) of hard wheat (Triticum durum Desf.). Biuletyn IHAR 2005, 237-238, 13-21.

21. Srinivasan, V.; Kumar, P.; Long, S.P. Decreasing, not increasing, leaf area will raise crop yields under global atmospheric change. Glob. Chang. Biol. 2016, 23, 1626-1635. [CrossRef]

22. Hirooka, Y.; Homma, K.; Maki, M.; Sekiguchi, K.; Shiraiwa, T.; Yoshida, K. Evaluation of the dynamics of the leaf area index (LAI) of rice in farmer's fields in Vientiane Province, Lao PDR. J. Agric. Meteorol. 2017, 73, 16-21. [CrossRef]

23. Fang, H.; Baret, F.; Plummer, S.; Schaepman-Strub, G. An overview of global leaf area index (LAI): Methods, products, validation, and applications. Rev. Geophys. 2019, 57, 739-799. [CrossRef]

24. Oleksy, A.; Szmigiel, A.; Kołodziejczyk, M. Yielding and leaf area development of selected winter wheat cultivars depending on technology level. Fragm. Agron. 2009, 26, 120-131.

25. Sobkowicz, P.; Tendziagolska, E.; Lejman, A. Performance of multi-component mixtures of spring cereals. Part 1. Yields and yield components. Acta Sci. Pol. Agric. 2016, 15, 25-35.

26. Klima, K.; Smaczny, M. Yielding and competitiveness of oats and spring vetch depending of cultivations systems and sowing method. J. Agric. Eng. Res. 2015, 60, 146-149.

27. Klima, K.; Łabza, T.; Lepiarczyk, A. Yielding of spring triticale grown under organic and integrated systems of farming and economic indicators of its production. J. Agric. Eng. Res. 2015, 60, 142-145.

28. Wanic, M.; Nowicki, J.; Kurowski, T.P. Regeneracja stanowisk w płodozmianach zbożowych poprzez stosowanie siewów mieszanych. Zesz. Probl. Postẹp. Nauk Rol. 2000, 470, 137-143.

29. Klimek-Kopyra, A.; Bacior, M.; Zając, T. Biodiversity as a creator of productivity and interspecific competitiveness of winter cereal species in mixed cropping. Ecol. Model. 2017, 343, 123-130. [CrossRef]

30. Vilich, V. Crop rotation with pure stands and mixtures of barley and wheat to control stem and root rot diseases. Crop. Prot. 1993, 12, 373-379. [CrossRef]

31. Atanasova, D.; Maneva, V.; Nedelcheva, T. Effect of predecessors on the productivity and phytosanitary condition of hull-less oats in organic farming. Agric. Sci. Technol. 2016, 8, 4-7. [CrossRef]

32. Bednarek, W.; Tkaczyk, P.; Dresler, S.; Jawor, E. Relationship between oat yield and some soil properties and nitrogen fertilization. Acta Agroph. 2013, 20, 29-38.

33. Buczek, J.; Tobiasz-Salach, R.; Bobrecka-Jamro, D. Assessment of yielding and weeding effects of mixed spring cereals. Zesz. Probl. Postęp. Nauk Rol. 2007, 516, 11-18.

34. Gawęda, D.; Nowak, A.; Haliniarz, M.; Woźniak, A. Yield and economic effectiveness of soybean grown under different cropping systems. Int. J. Plant Prod 2020, 1-11. [CrossRef]

35. Klima, K.; Kliszcz, A.; Puła, J.; Lepiarczyk, A. Yield and profitability of crop production in mountain less favoured areas. Agronomy 2020, 10, 700. [CrossRef]

36. IUSS Working Group WRB. World Reference Base for Soil Resources 2014, Update 2015, International Soil Classification System for Naming Soils and Creating Legends for Soil Maps; FAO: Rome, Italy, 2014; World Soil Resources Reports No. 106; Available online: http://www.fao.org/publications/card/en/c/942e424c-85a9-411da739-22d5f8b6cc41/ (accessed on 20 May 2020).

37. Lancashire, P.D.; Bleiholder, H.; Boom, T.V.D.; Langelüddeke, P.; Stauss, R.; Weber, E.; Witzenberger, A. A uniform decimal code for growth stages of crops and weeds. Ann. Appl. Biol. 1991, 119, 561-601. [CrossRef]

38. Mead, R.; Willey, R.W. The concept of a land equivalent ratio and advantages in yields for intercropping. Exp. Agric. 1980, 16, 217-228. [CrossRef]

39. Willey, R.W.; Rao, M.R. A competitive ratio for quantifying competition between intercrops. Exp. Agric. 1980, 16, 117-125. [CrossRef]

40. Tobiasz-Salach, R.; Bobrecka-Jamro, D.; Szpunar-Krok, E. Assessment of the productivity and mutual interactions between spring cereals in mixtures. Fragm. Agron. 2011, 28, 116-122.

41. Yu, Y.; Stomph, T.J.; Makowski, D.; van der Werf, W. Temporal niche differentiation increases the land equivalent ratio of annual intercrops: A meta-analysis. Field Crop. Res. 2015, 184, 133-144. [CrossRef]

42. Dhima, K.V.; Lithourgidis, A.S.; Vasilakoglou, I.B.; Dordas, C.A. Competition indices of common vetch and cereal intercrops in two seeding ratio. Field Crop. Res. 2007, 100, 249-256. [CrossRef]

43. Zalewski, A.; Chrościcki, J.; Oleksiak, T.; Trajner, M. Rynek środków produkcji i usług dla rolnictwa. In Analizy Rynkowe, 1st ed.; IERiGŻ: Warszawa, Poland, 2018; Volume 45, pp. 1-45.

44. Pobereźnik, B. Kalkulacje Produkcji Rolniczej, 1st ed.; Wydawnictwo MODR: Karniowice, Poland, 2018 ; p. 29. 
45. Klikocka, H.; Głowacka, A.; Juszczak, D. The influence of different soil tillage methods and mineral fertilization on the economic parameter of spring barley. Fragm. Agron. 2011, 28, 44-54.

46. Muzalewski, A. Koszty Eksploatacji Maszyn, 1st ed.; Wydawnictwo IBMER: Warszawa, Poland, 2009; p. 46.

47. Klepacki, B.; Gołębiewska, B. Opłacalność produkcji ziemniaków jadalnych. In Produkcja i Rynek Ziemniaków Jadalnych, 1st ed.; Chotkowski, J., Ed.; Wyd. Wieś Jutra: Warszawa, Poland, 2002; pp. 40-48.

48. Kumar, A.; van Duijnen, R.; Delory, B.M.; Reichel, R.; Brüggemann, N.; Temperton, V.M. Barley shoot biomass responds strongly to N:P stoichiometry and intraspecific competition, whereas roots only alter their foraging. bioRxiv 2020, 912352. [CrossRef]

49. Sobkowicz, P.; Podgórska-Lesiak, M. Experiments with crop mixtures: Interactions, designs and interpretation. Electron. J. Pol. Agric. Univ. 2007, 10, 22.

50. Narwal, S.S. Allelopathic interactions in multiple cropping systems. In Allelopathy in Ecological Agriculture and Forestry. Proceedings of the III International Congress on Allelopathy in Ecological Agriculture and Forestry, Dharwad, India, 18-21 August 1998; Narwal, S.S., Hoagland, R.E., Dilday, R.H., Reigosa, M.J., Eds.; Springer: Berlin, Germany, 2000; pp. 141-157.

51. Sobkowicz, P. Interspecies competition in spring cereal mixtures. Zesz. Nauk. AR Wrocław-Rozpr. 2003, 458, $1-105$.

52. Shaaf, S.; Bretani, G.; Biswas, A.; Fontana, I.M.; Rossini, L. Genetics of barley tiller and leaf development. J. Integr. Plant. Biol. 2019, 61, 226-256. [CrossRef]

53. Szarek, K. The competitiveness of spring cereals, cultivated as mixtures and pure sowings, depending on the sowing density. Acta Agrar. Silvest. Agrar. 2008, 51, 3-9.

54. Kaczmarek, S.; Matysiak, K.; Krawczyk, R. The effect of wheat, barley, and oat root system interactions, in two-species mixtures. J. Plant. Prot. Res. 2013, 53, 65-70. [CrossRef]

55. Sobkowicz, P. Above-ground and underground competition between barley and oat in the mixture in the initial period of growth. Fragm. Agron. 2001, 18, 103-119.

56. Cousens, R.D. Comparative growth of wheat, barley, and annual ryegrass (Lolium rigidum) in monoculture and mixture. Austral. J. Agric. Res. 1996, 47, 449-464. [CrossRef]

57. Hecht, V.L.; Temperton, V.M.; Nagel, K.A.; Raschel, U.; Postma, J.A. Sowing density: A neglected factor fundamentally affecting root distribution and biomass allocation of field grown spring barley (Hordeum vulgare L.). Front. Plant. Sci. 2016, 7, 1-14. [CrossRef]

58. Zając, T.; Oleksy, A.; Stokłosa, A.; Klimek-Kopyra, A.; Styrc, N.; Mazurek, R.; Budzyński, W. Pure sowings versus mixtures of winter cereal species as an effective option for fodder-grain production in temperate zone. Field Crop. Res. 2014, 166, 152-161. [CrossRef]

59. Stokłosa, A.; Stępnik, K. Development of differentiated in maturity period oats in mixture with spring barley. Fragm. Agron. 2009, 26, 116-125.

60. Liu, X.; Rahman, T.; Song, C.; Yang, F.; Su, B.; Cui, L.; Bu, W.; Yang, W. Relationships among light distribution, radiation use efficiency and land equivalent ratio in maize-soybean strip intercropping. Field Crop. Res. 2018, 224, 91-101. [CrossRef]

61. Sobkowicz, P.; Tendziagolska, E.; Lejman, A. Performance of multi-component mixtures of spring cereals. part 2. Competitive hierarchy and yield advantage of mixtures. Acta Sci. Pol. Agric. 2017, 15, 37-48.

62. Rudnicki, F. Impact of forecrop on yielding of various cereals in farm conditions. Fragm. Agron. 2005, 22, 172-182.

63. Rachoń, L.; Szumiło, G.; Michałek, W.; Bobryk-Mamczarz, A. Variability of leaf area index (LAI) and photosynthetic active radiation (PAR) depending on the wheat genotype and the intensification of cultivation technology. Agron. Sci. 2018, 73, 63-71. [CrossRef]

64. Crowder, D.W.; Reganold, J.P. Financial competitiveness of organic agriculture on a global scale. Proc. Nat. Acad. Sci. USA 2015, 112, 7611-7616. [CrossRef]

65. Seufert, V.; Ramankutty, N. Many shades of gray-The context-dependent performance of organic agriculture. Sci. Adv. 2017, 3, 1602638. [CrossRef]

66. Rosa-Schleich, J.; Loos, J.; Musshoff, O.; Tscharntke, T. Ecological-economic trade-offs of Diversified Farming Systems-A review. Ecol. Econ. 2019, 160, 251-263. [CrossRef]

67. White, K.E.; Cavigelli, M.A.; Conklin, A.E.; Rasmann, C. Economic performance of long-term organic and conventional crop rotations in the Mid-Atlantic. Agron. J. 2019, 111, 1358-1370. [CrossRef] 
68. Wieme, R.A.; Carpenter-Boggs, L.A.; Crowder, D.W.; Murphy, K.M.; Reganold, J.P. Agronomic and economic performance of organic forage, quinoa, and grain crop rotations in the Palouse region of the Pacific Northwest, USA. Agric. Syst. 2020, 177, 102709. [CrossRef] 